\title{
Herbage utilisation efficiency of continuously stocked marandu palisade grass subjected to nitrogen fertilisation
}

\author{
Lilian Elgalise Techio Pereira ${ }^{1}$, Adenilson José Paiva², Vitor Del'Álamo Guarda ${ }^{3}$, Priscila de Mesquita Pereira², Fábio Olegário \\ Caminha², Sila Carneiro da Silva $^{2 *}$
}

'University of São Paulo/FZEA - Av. Duque de Caxias Norte, 225, 13635-900 - Pirassununga, SP - Brazil.

2University of São Paulo/ESALQ - Animal Science Dept., Av. Pádua Dias, 11, C.P. 09 - 13418-900 - Piracicaba,

SP - Brazil.

${ }^{3}$ Embrapa Fisheries and Aquaculture, Quadra 103 Sul, Av. JK, Cj. 01, Lt. 17 - 77015-012 - Palmas, TO - Brazil.

*Corresponding author <siladasilva@usp.br >

Edited by: James Pierre Muir

Received January 16, 2014

Accepted August 02, 2014
ABSTRACT: Nitrogen fertiliser accelerates plant growth and increases herbage utilisation efficiency in continuously stocked temperate grass swards, indicating greater herbage production and harvest efficiency. There is no similar evidence, however, for tropical pastures. In this study we evaluated the morphogenetic responses, the patterns of defoliation and the efficiency of herbage utilisation of continuously stocked marandu palisade grass (Brachiaria brizantha (Hochst. ex A. Rich.) Stapf. cv. Marandu) maintained at $30 \mathrm{~cm}$ by cattle and fertilised with nitrogen. Treatments corresponded to four measures of nitrogen application (0, 150, 300 and $\left.450 \mathrm{~kg} \mathrm{ha}^{-1}\right)$, and were assigned to experimental units $\left(1,200 \mathrm{~m}^{2}\right.$ paddocks $)$ according to a randomised complete block design, with four replications. There was a seasonal pattern of variation in the morphogenetic responses and in herbage utilisation efficiency (HUE) characterised by higher herbage growth rates and HUE during late spring and summer. Nitrogen fertilisation increased both leaf appearance and elongation rates (around $60 \%$ between non-fertilised and swards fertilised with 450 $\mathrm{kg} \mathrm{ha}^{-1}, p<0.05$ ), requiring higher stocking rates (average of 1.6, 2.6, 2.9 and 3.1 Animal Unit (adult animal weighing $450 \mathrm{~kg}$ ) ha-1 for 0, 150, 300 and $450 \mathrm{~kg} \mathrm{ha}^{-1}$, respectively) to maintain the management target. Although the frequency of leaf defoliation increased (with no change in defoliation severity - $56.1 \pm 1.88 \%$ ), the leaf lifespan decreased, resulting in a similar number of defoliations during the leaf lifespan (average of $0.91 \pm 0.069$ ). This resulted in increased HUE only for the $150 \mathrm{~kg} \mathrm{ha}^{-1}$ treatment relative to non-fertilisation (37.5, 48.1, 44.0 and $44.5 \pm 2.25$ $\%$ for $0,150,300$ and $450 \mathrm{~kg} \mathrm{ha}^{-1} \mathrm{~N}$, respectively), indicating that with nitrogen fertilisation rates above $150 \mathrm{~kg} \mathrm{ha}^{-1}$, there are compensatory mechanisms related to morphogenetic responses that buffer changes in utilisation efficiency.

Keywords: Brachiaria brizantha, grazing management, leaf turnover, frequency and severity of defoliation

\section{Introduction}

The efficiency of herbage utilisation in a grazing system can be defined as the proportion of the gross leaf tissue production that is removed by the grazing animals before entering the senescent state (Lemaire and Chapman, 1996). Under rigid continuous stocking management, manipulation of herbage utilisation efficiency is relatively difficult because of the interdependence that exists between the frequency with which individual tillers are defoliated and the stocking rate (Lemaire et al., 2009). As a result, departures from the optimum range of sward conditions might be necessary on a regular basis in order to favor individual animal performance.

Nitrogen fertilisation can enhance the efficiency of herbage utilisation in continuously stocked temperate grass pastures due to the positive and concomitant effect of $\mathrm{N}$ on plant growth and the stocking rate necessary to maintain a given target of sward state (Mazzanti and Lemaire, 1994). The linear decrease in senescence flux normally observed under these circumstances reflects the more than proportional increase in stocking rate required to maintain a "sward state" (Lemaire and Agnusdei, 2000) which, in turn, directly increases the frequency of defoliation of tillers and the efficiency of herbage utilisation for a given leaf lifespan (Lemaire et al., 2009). In this context, nitrogen fertilisation would increase herbage accumulation through the acceleration of morphogenetic processes linked to growth - leaf elongation, leaf appearance and final leaf length - and also improve utilisation efficiency, increasing productivity and competitiveness of livestock production without compromising the sustainability of grassland systems (Lemaire et al., 2009). Evidence of this nature for tropical grass species is still scarce, and could contribute to improving the overall system productivity in tropical areas of the globe, helping to overcome the trade-off between animal performance and herbage utilisation efficiency.

Against this background, the aim of our experiment was to evaluate the morphogenetic responses, the patterns of defoliation and the efficiency of herbage utilisation of continuously stocked marandu palisade grass subjected to measured nitrogen fertilisation.

\section{Materials and Methods}

The experiment was carried out at Piracicaba, in the state of São Paulo, Brazil $\left(22^{\circ} 42^{\prime}\right.$ S, 47 $7^{\circ} 37^{\prime} \mathrm{W}$ and $550 \mathrm{~m}$ a.s.1.), on a Brachiaria brizantha (Hochst. ex A. Rich.) Stapf. cv. Marandu pasture (marandu palisade 
grass) established in 2001 on a Eutric Kandiudalf. Average soil chemical characteristics for the $0-20 \mathrm{~cm}$ layer were: $\mathrm{pH} 0.01 \mathrm{M} \mathrm{CaCl}_{2}: 5.1 ; \mathrm{OM}=41 \mathrm{dg} \mathrm{dm}^{-3} ; \mathrm{P}$ (ion-exchange resin extraction method) $=62 \mathrm{mg} \mathrm{dm}^{-3} ; \mathrm{Ca}=60 \mathrm{mmol}_{\mathrm{c}}$ $\mathrm{dm}^{-3}, \mathrm{Mg}=16 \mathrm{mmol}_{\mathrm{c}} \mathrm{dm}^{-3} ; \mathrm{K}=6.4 \mathrm{mmol}_{\mathrm{c}} \mathrm{dm}^{-3} ; \mathrm{H}+\mathrm{Al}$ $=44 \mathrm{mmol}_{\mathrm{c}} \mathrm{dm}^{-3}$; sum of bases $=82.5 \mathrm{mmol}_{\mathrm{c}} \mathrm{dm}^{-3}$; cation exchange capacity $=124.5 \mathrm{mmol}_{\mathrm{c}} \mathrm{dm}^{-3}$; base saturation $=65 \%$. These soil attributes were considered adequate for this forage species, with no need for additional fertilisation, except nitrogen (Werner et al., 1996). Average air temperature for summer I (Jan to Mar, 2007), autumn (Apr to Jun, 2007), winter (Jul to Sept, 2007) and early spring (Oct to Nov, 2007) was relatively higher than the 90-year average (1917 to 2007). Rainfall for summer I and for autumn, winter, spring and summer II (Jan to Mar, 2008, except Jan 2008) was higher and lower, respectively, than the historical values (Figure 1).

The experimental area comprised four blocks containing four $1,200 \mathrm{~m}^{2}$ paddocks each, all equipped with water and shaded mineral salt troughs. Prior to this study, the area was used for a series of grazing experiments on continuous stocking management (2001 to 2006). At the end of those experiments the area was kept under rotational grazing by beef cattle until Mar 2006 and then staged at $10 \mathrm{~cm}$ in Apr in preparation for the present experiment. Based on the results of the previous series of experiments under continuous stocking (Da Silva and Nascimento Júnior, 2007), a sward surface height of 30 $\mathrm{cm}$ was defined as the experimental management target for optimized herbage growth, animal performance and productivity.

Monitoring of sward surface height started soon after staging. The procedure was performed weekly until swards had reached around $20 \mathrm{~cm}$, and twice a week afterwards. For that purpose, a sward stick (Barthram, 1985) was used to record a total of 100 readings per paddock along four transects ( 25 points per transect) arranged in a zigzag pattern. A tolerance range of \pm 10 $\%$ was established for variations around the $30 \mathrm{~cm}$ target for sward surface height $(27$ to $33 \mathrm{~cm})$. As the lower limit of the range was reached, animals started to be placed in

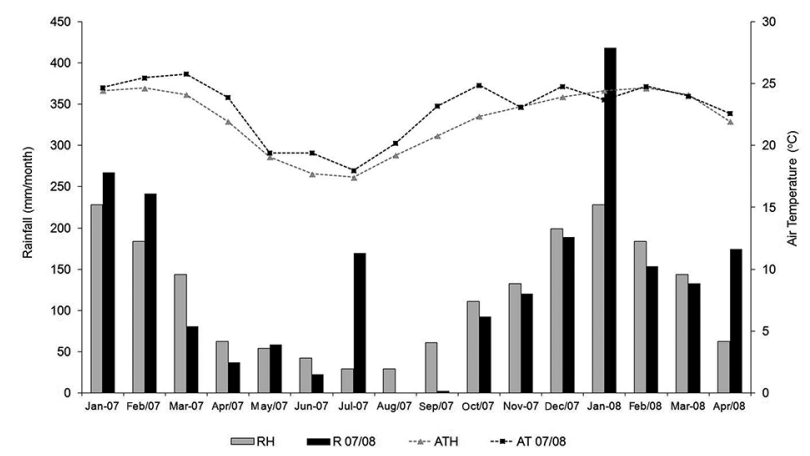

Figure 1 - Monthly (R 2007/2008) and historical (RH 1917 to 2007) means of rainfall and air temperature (AT 07/08 and ATH 2007/2008). paddocks, from Oct 2006 onwards. Animals were added or removed from paddocks according to the need to keep the sward target relatively stable around $30 \mathrm{~cm}$. Grazing was carried out by Nelore (Bos taurus indicus) and Canchim (3/8 Charolais - Bos taurus taurus $-\times 5 / 8 \mathrm{Zebu}$ - Bos taurus indicus - crossbred) heifers with an average initial body weight of 250 to $280 \mathrm{~kg}$.

Four fertilisation treatments were applied: 0, 150, 300 and $450 \mathrm{~kg} \mathrm{ha}^{-1} \mathrm{~N}$ using pure ammonium nitrate. The total measure was applied in four equal dressings throughout the year in the following dates: Year 1 - Dec 19, 2006; Jan 16, 2007; Feb 23, 2007 and Mar 23, 2007; Year 2 - Dec 20, 2007; Jan 17, 2008; Feb 14, 2008 and Mar 13, 2008. The experiment comprised a randomised complete block design, with four replicates. Evaluations initiated only after all 16 paddocks (experimental units) reached the sward target of $30 \mathrm{~cm}$ and were continuously stocked by cattle, a condition that occurred only after Dec 2006. For this reason, the experimental period started only in Jan 2007 and finished in Apr 2008, comprising two entire consecutive pasture growing seasons (2006/2007 and 2007/2008). The present experiment is one of a series of experiments carried out concomitantly in the same area with the general aim of evaluating sward structure, herbage accumulation dynamics, tiller population demography and dynamics, patterns of defoliation and ingestive behaviour of the grazing animals (e.g. Caminha et al., 2010; Mesquita et al., 2010; Pereira et al., 2010; Paiva et al., 2011; Paiva et al., 2012).

Herbage samples were harvested in each season of the year using a $0.90 \times 0.37 \mathrm{~m}\left(0.999 \mathrm{~m}^{2}\right)$ metallic frame, which was randomly placed on three areas inside the paddocks that represented the average sward condition at sampling time (visual assessment of sward height and herbage mass). All herbage within the frame was cut to ground level, subsampled and hand dissected into the morphological components leaf (leaf lamina), stem (stem + leaf sheath) and dead material. The area of leaf lamina was measured using a leaf area integrator before drying in a forced air oven at $65{ }^{\circ} \mathrm{C}$ until constant weight. Results were used to calculate the sward leaf area index (LAI). At the end of the experiment, samples from the last fully expanded leaf were harvested from each paddock (60 leaves) to determine nitrogen concentration and inferences about the nitrogen nutrition status of plants (Batista and Monteiro, 2007).

Measurements of the morphogenetic and structural characteristics were taken of 30 individually tagged tillers per paddock. These were marked using coloured plastic coated wire along three transect lines each two meters long placed on representative areas of the paddocks (visual assessment of sward herbage mass and height). Tillers were monitored twice a week during four weeks in summer and late spring (periods of fast plant growth) and once a week for eight weeks in autumn/winter and early spring (periods of slow plant growth). On some occasions a number of tagged tillers disappeared and were replaced by new tillers in order to maintain a 
minimum of 25 tagged tillers per paddock. At the end of each measurement period a new set of tillers was randomly chosen and tagged to start the following period of measurements. In each evaluation procedure basal and aerial tillers were identified and their leaves numbered and classified as expanding (ligule not visible), expanded (visible ligule and/or no change in lamina length from previous measurement date - at times ligules were hidden under the sheath of older leaves), senescing (lamina with signs of yellowing/browning) and dead (senescence on more than $50 \%$ of the lamina length).

Leaves were also classified as intact or defoliated. Measurements of lamina length were taken of all leaves in each category. On expanded leaves, the length was measured from the tip of the leaf to its ligule. On expanding leaves, the procedure was the same except that the ligule of the last expanded leaf was used as a reference. On senescing leaves, measurements were taken from the ligule to the border line between the green and the yellow/brown-senescing tissue on the leaf lamina. Measurements of stem length were taken from the point of origin of the tagged tiller (soil level or point of insertion on the parent tiller for basal and aerial tillers, respectively) to the ligule of the last expanded leaf. Stems were considered senescent when all leaves had disappeared and the remaining tissues were brown and sapless (not only the attached sheaths).

The results were used to calculate the following variables: leaf appearance rate (LAR, leaf per tiller $\left.\mathrm{d}^{-1}\right)$, leaf elongation rate (LER, cm per tiller $\left.\mathrm{d}^{-1}\right)$, stem elongation rate (SER, cm per tiller $\left.\mathrm{d}^{-1}\right)$, leaf senescence rate (LSR, cm per tiller $\left.\mathrm{d}^{-1}\right)$, number of live leaves per tiller (NLL), final lamina length (FLL) of expanded leaves $(\mathrm{cm})$, stem length $(\mathrm{SL}, \mathrm{cm})$ and phyllochron (PHY), which was calculated as the inverse of LAR. The leaf lifespan (LLS) was estimated as the product between PHY and NLL. A base temperature of $15^{\circ} \mathrm{C}$ (Mendonça and Rassini, 2006) was used to calculate LLS and PHY values in degree-days $\left({ }^{\circ} \mathrm{C}\right.$-d).

Herbage utilisation efficiency was calculated according to Mazzanti and Lemaire (1994) through variations in leaf lamina length. The average number of defoliation events per tiller (ND) during each evaluation period was determined by the sum of the number of defoliations divided by the total number of marked tillers. The frequency of defoliation (FD, number of defoliations per tiller $\mathrm{d}^{-1}$ ) was obtained by dividing ND by the duration (days) of the evaluation periods. The severity of defoliation (SD) for each leaf category corresponded to the difference between the initial and the final leaf lamina length expressed as percentage of the initial length. The number of defoliation events during the leaf lifespan $\left(\mathrm{ND}_{\text {LLS }}\right)$ was given by: $\mathrm{ND}_{\text {LLS }}=\mathrm{FD} \times \mathrm{LLS}$.

Data were analysed using the Mixed Procedure from SAS ${ }^{\circledR}$ (Statistical Analysis System). The choice of covariance matrix was made using the Akaike Information Criterion (AIC) (Wolfinger, 1993). Nitrogen fertilisation, season of the year and their interaction were considered as fixed effects and blocks as random effects. Season of the year was treated as a repeated measure. When appropriate, treatment means were calculated using the "LSMEANS" statement and comparisons were made using the Student test at $5 \%$.

\section{Results}

The control of experimental conditions was efficient, with sward height maintained very close to specification $(30 \mathrm{~cm} \pm 10 \%)$. Stocking rate varied with nitrogen fertilisation treatment and season of the year, and sward leaf area index (LAI) increased consistently with $\mathrm{N}$ fertilisation rate throughout the experiment (Table 1). Nitrogen concentration in the last fully expanded leaf increased as the nitrogen application rate increased $(p=$ $0.0004)$, with average values of $12.8 \pm 0.94,13.9 \pm 1.73$, $18.3 \pm 2.21$ and $22.6 \pm 2.54 \mathrm{~g} \mathrm{~kg}^{-1}$ for $0,150,300$ and $450 \mathrm{~kg} \mathrm{ha}^{-1} \mathrm{~N}$, respectively.

\section{Morphogenetic characteristics}

Leaf appearance and elongation rate (LAR and LER) varied with nitrogen fertilisation $(p=0.0083$ and $p=0.0304)$, season of the year $(p<0.0001$ for both variables) and the nitrogen fertilisation $\times$ season of the year interaction $(p=0.0169$ and $p=0.0098$, respectively). LAR values increased with fertilisation in summer I. During autumn/winter lower values of LAR were observed in swards fertilised with $150 \mathrm{~kg} \mathrm{ha}^{-1} \mathrm{~N}$ relative to those fertilised with 300 and $450 \mathrm{~kg} \mathrm{ha}^{-1} \mathrm{~N}$, differences disappearing during early spring. Higher values were registered in swards fertilised with $450 \mathrm{~kg} \mathrm{ha}^{-1} \mathrm{~N}$ during

Table 1 - Sward surface height (SSH, cm), stocking rate (SR, Animal units ha-1) and leaf area index (LAl) of continuously stocked marandu palisade grass maintained at $30 \mathrm{~cm}$ and fertilised with nitrogen from Jan 2007 to Apr 2008.

\begin{tabular}{|c|c|c|c|c|c|c|c|c|c|c|c|c|c|c|c|}
\hline \multirow{2}{*}{ Rate (kg N ha-1) } & \multicolumn{3}{|c|}{ Summer I } & \multicolumn{3}{|c|}{ Autumn/Winter } & \multicolumn{3}{|c|}{ Early spring } & \multicolumn{3}{|c|}{ Late Spring } & \multicolumn{3}{|c|}{ Summer II } \\
\hline & SSH & SR & $\mathrm{LAl}^{1}$ & $\mathrm{SSH}$ & SR & LAl & $\mathrm{SSH}$ & SR & LAl & SSH & SR & LAl & $\mathrm{SSH}$ & SR & LAl \\
\hline Non-fertilised & 28.9 & 2.1 & $2.97 \mathrm{Ba}$ & 29.3 & 0.7 & $2.13 \mathrm{Dab}$ & 28.7 & 0.4 & $1.07 \mathrm{Cc}$ & 29.9 & 2.5 & $2.10 \mathrm{Bb}$ & 30.1 & 2.3 & $2.13 \mathrm{Bab}$ \\
\hline 150 & 29.0 & 3.2 & $3.10 \mathrm{Ba}$ & 29.5 & 0.3 & $3.00 \mathrm{Cab}$ & 29.2 & 0.8 & $1.89 \mathrm{BCb}$ & 30.2 & 3.6 & 2.60 Bab & 30.2 & 5.1 & $2.77 \mathrm{Ba}$ \\
\hline 300 & 29.0 & 3.4 & 4.25 Aab & 29.7 & 0.7 & $4.24 \mathrm{Ba}$ & 29.6 & 1.1 & $2.45 \mathrm{ABC}$ & 30.3 & 3.7 & $3.53 \mathrm{Ab}$ & 30.3 & 5.6 & 4.21 Aab \\
\hline 450 & 29.3 & 4.1 & $4.03 \mathrm{Ab}$ & 29.8 & 0.6 & $4.97 \mathrm{Aa}$ & 29.6 & 1.4 & $3.29 \mathrm{Ab}$ & 30.2 & 4.1 & $3.63 \mathrm{Ab}$ & 30.1 & 5.2 & $4.95 \mathrm{Aa}$ \\
\hline SEM & 0.21 & 0.43 & 0.260 & 0.24 & 0.12 & 0.190 & 0.29 & 0.15 & 0.289 & 0.16 & 0.26 & 0.151 & 0.07 & 0.35 & 0.289 \\
\hline
\end{tabular}

1Data published by Mesquita et al. (2010); Aaln LAl, means followed by the same letters, uppercase in columns and lowercase in rows, are not different ( $p>0.05$ ); $\mathrm{SEM}=$ Standard error of the mean. 
late spring and fertilised with 300 and $450 \mathrm{~kg} \mathrm{ha}^{-1} \mathrm{~N}$ relative to those non-fertilised during summer II.

For LER, larger values were recorded in swards fertilised with 300 and $450 \mathrm{~kg} \mathrm{ha}^{-1} \mathrm{~N}$, except during early spring when no differences were recorded (Table 2). Stem elongation rate (SER) varied only with the season of the year $(p<0.0001)$, with larger values recorded during summer I and II $\left(0.06\right.$ and $0.08 \mathrm{~cm}$ per tiller $\mathrm{d}^{-1}$, respectively). Recorded values during autumn/winter, early and late spring were similar, and corresponded to $63 \%$ of those recorded during summer I and II.

Rates of leaf senescence (LSR) varied with the season of the year $(p<0.0001)$ and the nitrogen fertilisation $\times$ season of the year interaction $(p=0.0037)$, with differences between nitrogen application rates recorded only in summer I and II. During summer I, larger values were recorded for non-fertilised swards than for those fertilised with $300 \mathrm{~kg} \mathrm{ha}^{-1} \mathrm{~N}$, while those swards fertilised with 150 and $450 \mathrm{~kg} \mathrm{ha}^{-1} \mathrm{~N}$ were no different from any other treatment. During summer II, larger values were recorded on swards fertilised with $450 \mathrm{~kg} \mathrm{ha}^{-1} \mathrm{~N}$, which did not differ from those fertilised with $300 \mathrm{~kg} \mathrm{ha}^{-1} \mathrm{~N}$ but were higher than those fertilised with $150 \mathrm{~kg} \mathrm{ha}^{-1} \mathrm{~N}$ or non-fertilised (Table 2).

Leaf lifespan (LLS) varied with the season of the year $(p<0.0001)$ and the nitrogen fertilisation $\times$ season of the year interaction ( $p=0.0063)$. Overall, LLS was shorter during late spring, summer I and summer II, longer during early spring, and intermediate during autumn/ winter. Early spring was the only season of the year with no differences between nitrogen fertilisation treatments. During summer I, LLS was longer in non-fertilised swards relative to those fertilised with 300 and $450 \mathrm{~kg} \mathrm{ha}^{-1} \mathrm{~N}$. During autumn/winter, larger values were recorded for swards fertilised with $150 \mathrm{~kg} \mathrm{ha}^{-1} \mathrm{~N}$, which were similar to those of non-fertilised swards, but larger than those fertilised with 300 and $450 \mathrm{~kg} \mathrm{ha}^{-1} \mathrm{~N}$. Differences during late spring were recorded only between non-fertilised and swards fertilised with $450 \mathrm{~kg} \mathrm{ha}^{-1} \mathrm{~N}$, with longer LLS for the former, and during summer II the only difference was between non-fertilised and fertilised swards, with longer LLS for non-fertilised swards (Table 3).

\section{Structural characteristics}

The number of live leaves per tiller (NLL) remained stable and around 3.5 to 3.8 throughout the experimental period, regardless of nitrogen fertilisation treatment. Final leaf lamina length (FLL) was influenced by nitrogen fertilisation ( $p=0.0319)$, season of the year $(p=0.0131)$ and the nitrogen fertilisation $\times$ season of the year interaction $(p=0.0431)$. Treatment differences were recorded only in early spring between non-fertilised and swards fertilised with $450 \mathrm{~kg} \mathrm{ha}^{-1} \mathrm{~N}$, and in summer II between swards fertilised with 300 or $450 \mathrm{~kg} \mathrm{ha}^{-1} \mathrm{~N}$ and those non-fertilised or fertilised with $150 \mathrm{~kg} \mathrm{ha}^{-1} \mathrm{~N}$ (Table 4). Stem length (SL) varied with the season of the year $(p$ $=0.0131)$ and the nitrogen fertilisation $\times$ season of the year interaction $(p=0.0431)$. Treatment differences were recorded only during summer II, when swards fertilised with $150 \mathrm{~kg} \mathrm{ha}^{-1} \mathrm{~N}$ showed the lowest SL, although not different from swards fertilised with 300 and $450 \mathrm{~kg} \mathrm{ha}^{-1}$ $\mathrm{N}$ (Table 4).

\section{Patterns of defoliation and herbage utilisation ef-} ficiency (HUE)

The severity of defoliation of individual leaves (DS) varied only with the season of the year $(p<0.0001)$,

Table 2 - Leaf appearance rate (LAR), leaf elongation rate (LER) and leaf senescence rate (LSR) of continuously stocked marandu palisade grass maintained at $30 \mathrm{~cm}$ and fertilised with nitrogen from Jan 2007 to Apr 2008.

\begin{tabular}{|c|c|c|c|c|c|}
\hline Rate (kg N ha-1) & Summer I & Autumn/Winter & Early Spring & Late Spring & Summer II \\
\hline \multicolumn{6}{|c|}{ LAR (leaf per tiller $\mathrm{d}^{-1}$ ) } \\
\hline Non-fertilised & $0.061 \mathrm{Da}$ & $0.040 \mathrm{ABb}$ & $0.039 \mathrm{Ab}$ & $0.068 \mathrm{Ba}$ & $0.062 \mathrm{Ba}$ \\
\hline 150 & $0.078 \mathrm{Ca}$ & $0.039 \mathrm{Bb}$ & $0.040 \mathrm{Ab}$ & $0.081 \mathrm{ABa}$ & $0.079 \mathrm{ABa}$ \\
\hline 300 & $0.089 \mathrm{Bab}$ & $0.050 \mathrm{Ac}$ & $0.038 \mathrm{Ac}$ & $0.075 \mathrm{Bb}$ & $0.096 \mathrm{Aa}$ \\
\hline 450 & $0.102 \mathrm{Aa}$ & $0.050 \mathrm{Ab}$ & $0.046 \mathrm{Ab}$ & $0.097 \mathrm{Aa}$ & $0.098 \mathrm{Aa}$ \\
\hline SEM & 0.0033 & 0.0051 & 0.0071 & 0.0068 & 0.0079 \\
\hline \multicolumn{6}{|c|}{ LER (cm per tiller $\mathrm{d}^{-1}$ ) } \\
\hline Non-fertilised & $0.79 \mathrm{Cb}$ & $0.44 \mathrm{Bc}$ & $0.69 \mathrm{Ab}$ & $0.84 \mathrm{Bab}$ & $1.05 \mathrm{Ca}$ \\
\hline 150 & $1.05 \mathrm{BCa}$ & $0.42 \mathrm{Bc}$ & $0.68 \mathrm{Ab}$ & $0.95 \mathrm{ABa}$ & $1.13 \mathrm{BCa}$ \\
\hline 300 & $1.24 \mathrm{ABb}$ & $0.58 \mathrm{Ac}$ & $0.67 \mathrm{Ac}$ & $1.12 \mathrm{ABb}$ & $1.50 \mathrm{Aa}$ \\
\hline 450 & $1.50 \mathrm{Aa}$ & $0.58 \mathrm{Ac}$ & $0.64 \mathrm{Ac}$ & $1.23 \mathrm{Ab}$ & $1.41 \mathrm{ABab}$ \\
\hline SEM & 0.121 & 0.033 & 0.097 & 0.105 & 0.110 \\
\hline \multicolumn{6}{|c|}{ LSR (cm per tiller $\mathrm{d}^{-1}$ ) } \\
\hline Non-fertilised & $0.116 \mathrm{Aa}$ & $0.075 \mathrm{Ab}$ & $0.157 \mathrm{Aa}$ & $0.120 \mathrm{Abc}$ & $0.058 \mathrm{BCc}$ \\
\hline 150 & $0.090 \mathrm{ABab}$ & $0.068 \mathrm{Abc}$ & $0.127 \mathrm{Aa}$ & 0.079 Aabc & $0.043 \mathrm{Cc}$ \\
\hline 300 & $0.068 \mathrm{Bb}$ & $0.092 \mathrm{Ab}$ & $0.154 \mathrm{Aa}$ & $0.075 \mathrm{Ab}$ & $0.077 \mathrm{ABb}$ \\
\hline 450 & $0.078 \mathrm{ABb}$ & $0.074 \mathrm{Ab}$ & $0.150 \mathrm{Aa}$ & $0.076 \mathrm{Ab}$ & $0.087 \mathrm{Ab}$ \\
\hline SEM & 0.0077 & 0.0084 & 0.0124 & 0.0230 & 0.0077 \\
\hline
\end{tabular}

AaMeans followed by the same letters, uppercase in columns and lowercase in rows, are not different $(p>0.05)$; SEM = Standard error of the mean. 
with higher similar values recorded during summer I, late spring and summer II $(61.7 \pm 2.18,62.4 \pm 1.59$ and $63.9 \pm 1.76 \%$, respectively), lower values recorded in early spring $(37.9 \pm 2.37 \%)$ and intermediate values in autumn/winter $(54.8 \pm 3.37 \%)$. Average DS corresponded to $53.7,56.4,56.4$ and $58.1 \pm 1.88 \%$ for non-fertilised and swards fertilised with 150, 300 and $450 \mathrm{~kg} \mathrm{ha}^{-1} \mathrm{~N}$, respectively.

The frequency of defoliation of leaves (DF) varied with nitrogen fertilisation $(p=0.0003)$, season of the year $(p<0.0001)$ and the nitrogen fertilisation $\times$ season of the year interaction $(p=0.0014)$. During summer I, lower values were recorded for non-fertilised relative to fertilised swards. During autumn/winter, lower values were recorded for swards fertilised with $150 \mathrm{~kg} \mathrm{ha}^{-1} \mathrm{~N}$ relative to those fertilised with $300 \mathrm{~kg} \mathrm{ha}^{-1} \mathrm{~N}$. In early and late spring, large differences were recorded between nonfertilised and swards fertilised with $450 \mathrm{~kg} \mathrm{ha}^{-1} \mathrm{~N}$, with similar intermediate values for those fertilised with 150 and $300 \mathrm{~kg} \mathrm{ha}^{-1} \mathrm{~N}$. During summer II, higher values were recorded for swards fertilised with 300 and $450 \mathrm{~kg} \mathrm{ha}^{-1} \mathrm{~N}$ relative to the non-fertilised (Figure 2).
The number of defoliations during leaf lifespan varied only with the season of the year $(p<0.0001)$, with higher values recorded during early spring $(1.78$ $\pm 0.163)$, lower during summer I $(0.62 \pm 0.038)$ and autumn/winter $(0.57 \pm 0.043)$, and similar intermediate values during late spring $(0.79 \pm 0.036)$ and summer II $(0.82 \pm 0.039)$. There was no difference between nitrogen fertilisation treatments, with average values of $0.85,0.89,0.98$ and $0.94 \pm 0.069$ for non-fertilised swards and those fertilised with 150, 300 and $450 \mathrm{~kg} \mathrm{ha}^{-1}$ of $\mathrm{N}$, respectively.

Herbage utilisation efficiency (HUE, \%) varied with nitrogen fertilisation $(p=0.0048)$ and season of the year $(p<0.0001)$. In general, higher values were recorded during summer I, late spring and summer II $(46.6,51.3$ and $56.0 \pm 2.55 \%$, respectively) and lower values during autumn/winter and early spring $(30.8$ and $32.8 \pm 2.55 \%$, respectively). HUE was highest for swards fertilised with $150 \mathrm{~kg} \mathrm{ha}^{-1} \mathrm{~N}$ with similar values between the remaining treatments $(37.5,48.1,44.0$ and $44.5 \pm 2.25 \%$ for non-fertilised and swards fertilised with 150, 300 and $450 \mathrm{~kg} \mathrm{ha}^{-1} \mathrm{~N}$, respectively) (Figure 3).

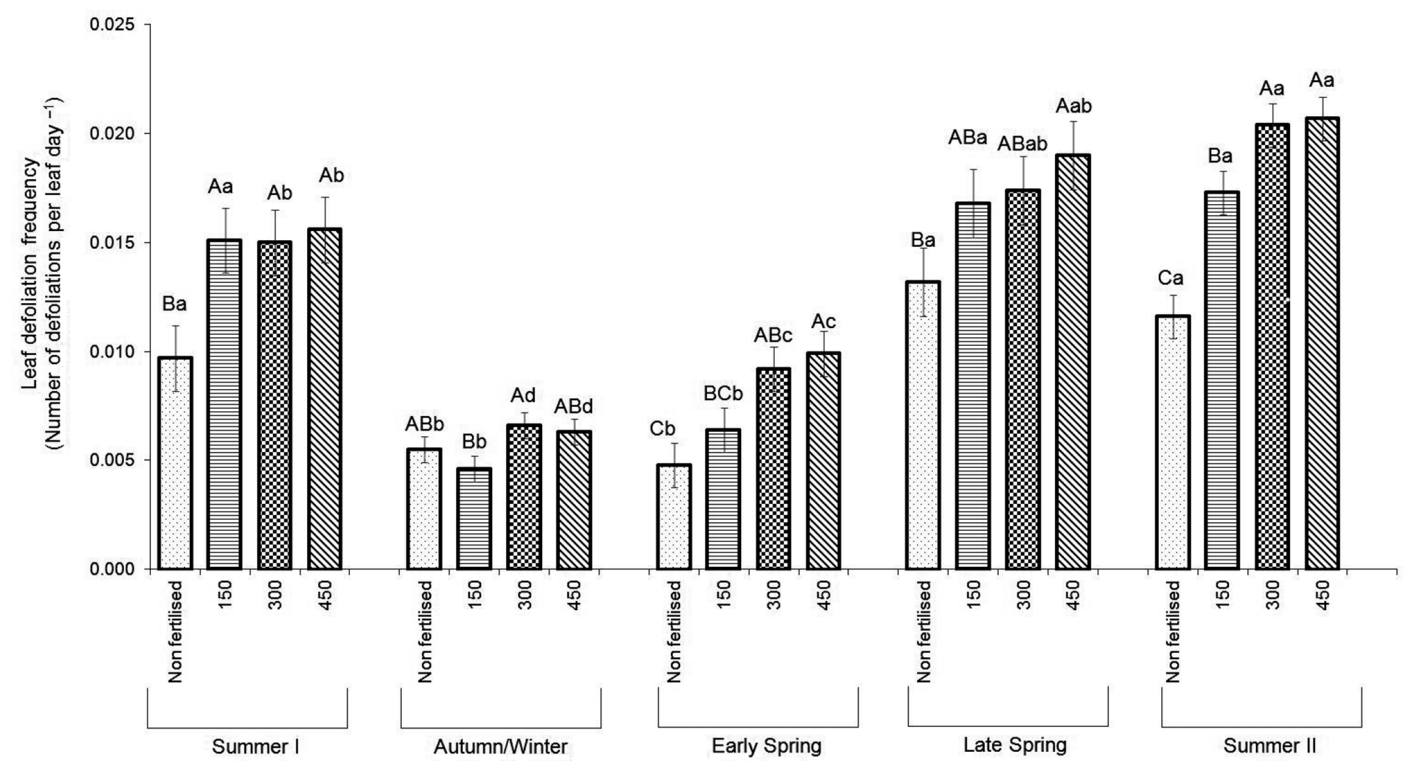

Figure 2 - Leaf defoliation frequency of continuously stocked marandu palisade grass maintained at $30 \mathrm{~cm}$ and fertilised with nitrogen from Jan 2007 to Apr 2008. Means followed by the same uppercase letters within seasons of the year and lowercase letters within rates of nitrogen application are not different $(p>0.05)$; Bars on top of each series represent the standard error of the mean.

Table 3 - Leaf lifespan of continuously stocked marandu palisade grass maintained at $30 \mathrm{~cm}$ and fertilised with nitrogen from Jan 2007 to Apr 2008.

\begin{tabular}{llllll}
\hline Rate $\left(\mathrm{kg} \mathrm{N} \mathrm{ha}^{-1}\right)$ & Summer I & \multicolumn{1}{l}{ Autumn/Winter } & Early Spring & Late Spring & Summer II \\
\hline Non-fertilised & \multicolumn{5}{c}{ Leaf lifespan ( ${ }^{\circ} \mathrm{C}-\mathrm{d}$ per leaf) } \\
150 & $638 \mathrm{Ab}$ & $602 \mathrm{ABbc}$ & $2118 \mathrm{Aa}$ & $509 \mathrm{Ac}$ & $660 \mathrm{Abc}$ \\
300 & $496 \mathrm{ABbc}$ & $711 \mathrm{Ab}$ & $2299 \mathrm{Aa}$ & $445 \mathrm{ABc}$ & $443 \mathrm{Bc}$ \\
450 & $416 \mathrm{Bbc}$ & $504 \mathrm{Bb}$ & $2377 \mathrm{Aa}$ & $449 \mathrm{ABbc}$ & $338 \mathrm{Bc}$ \\
SEM & $359 \mathrm{Bbc}$ & $481 \mathrm{Bb}$ & $2394 \mathrm{Aa}$ & $332 \mathrm{Bbc}$ & $329 \mathrm{Bc}$ \\
\hline
\end{tabular}

AaMeans followed by the same letters, uppercase in columns and lowercase in rows, are not different $(p>0.05)$; SEM= Standard error of the mean. 
Pereira et al.

Herbage utilisation of marandu palisade grass

Table 4 - Final leaf length (FLL) and stem length (SL) of continuously stocked marandu palisade grass maintained at $30 \mathrm{~cm}$ and fertilised with nitrogen from Jan 2007 to Apr 2008.

\begin{tabular}{|c|c|c|c|c|c|}
\hline Rate (kg N ha-1) & Summer I & Autumn/Winter & Early Spring & Late Spring & Summer II \\
\hline \multicolumn{6}{|c|}{ FLL $(\mathrm{cm})$} \\
\hline Non-fertilised & $13.6 \mathrm{Abc}$ & $13.8 \mathrm{Bc}$ & $17.8 \mathrm{Ba}$ & 16.0 Aabc & $15.4 \mathrm{Bb}$ \\
\hline 150 & $15.3 \mathrm{Ac}$ & 17.6 Aab & $19.8 \mathrm{ABa}$ & 16.3 Abc & $14.4 \mathrm{Bc}$ \\
\hline 300 & $14.3 \mathrm{Ac}$ & 16.7 Ab & $20.1 \mathrm{ABa}$ & $15.8 \mathrm{Abc}$ & $18.9 \mathrm{Aa}$ \\
\hline 450 & $16.0 \mathrm{Ab}$ & 16.4 Ab & $21.2 \mathrm{Aa}$ & $16.1 \mathrm{Ab}$ & $17.7 \mathrm{Ab}$ \\
\hline SEM & 0.95 & 0.59 & 1.03 & 1.34 & 0.50 \\
\hline \multicolumn{6}{|c|}{ SL (cm) } \\
\hline Non-fertilised & 17.4 Aab & 16.9 Aab & $15.4 \mathrm{Ab}$ & $15.0 \mathrm{Ab}$ & $18.4 \mathrm{Aa}$ \\
\hline 150 & 16.4 Aab & $16.5 \mathrm{Aa}$ & $14.6 \mathrm{Ab}$ & 15.3 Aab & $13.8 \mathrm{Bb}$ \\
\hline 300 & $15.8 \mathrm{Aa}$ & $17.6 \mathrm{Aa}$ & $16.5 \mathrm{Aa}$ & $17.6 \mathrm{Aa}$ & $17.0 \mathrm{ABa}$ \\
\hline 450 & $15.5 \mathrm{Aa}$ & $17.0 \mathrm{Aa}$ & 16.8 Aa & 15.7 Aa & $15.6 \mathrm{ABa}$ \\
\hline SEM & 0.95 & 1.16 & 1.27 & 1.65 & 1.14 \\
\hline
\end{tabular}

AaMeans followed by the same letters, uppercase in columns and lowercase in rows, are not different $(p>0.05)$; SEM= Standard error of the mean.

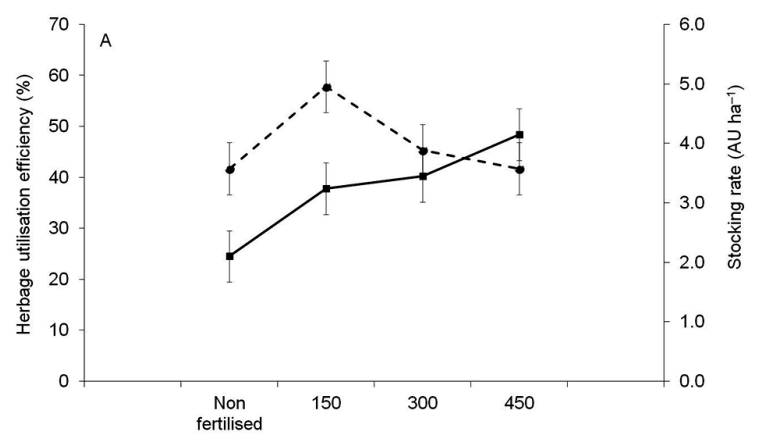

Nitrogen fertilisation rate $\left(\mathrm{kg} \mathrm{ha}^{-1}\right)$

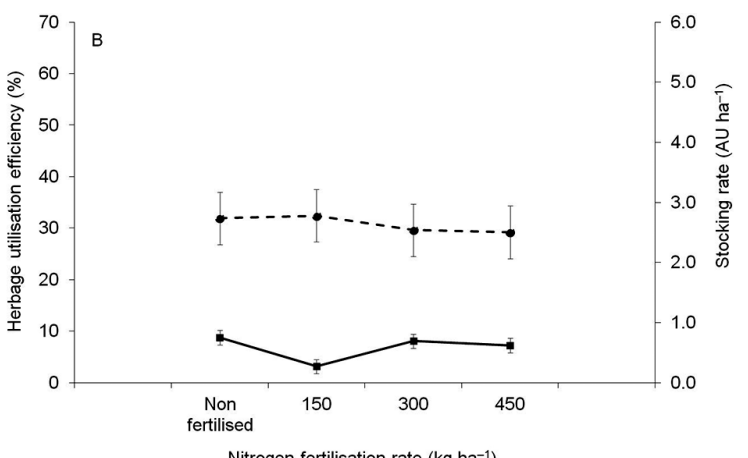

Nitrogen fertilisation rate $\left(\mathrm{kg} \mathrm{ha}^{-1}\right)$

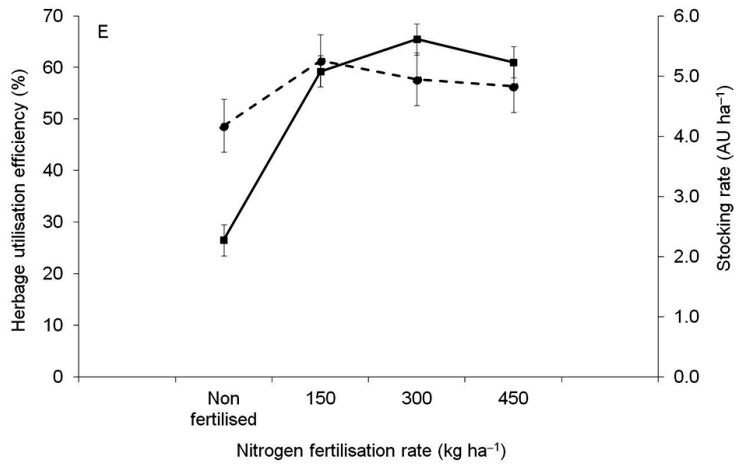

Nitrogen fertilisation rate $\left(\mathrm{kg} \mathrm{ha}^{-1}\right)$
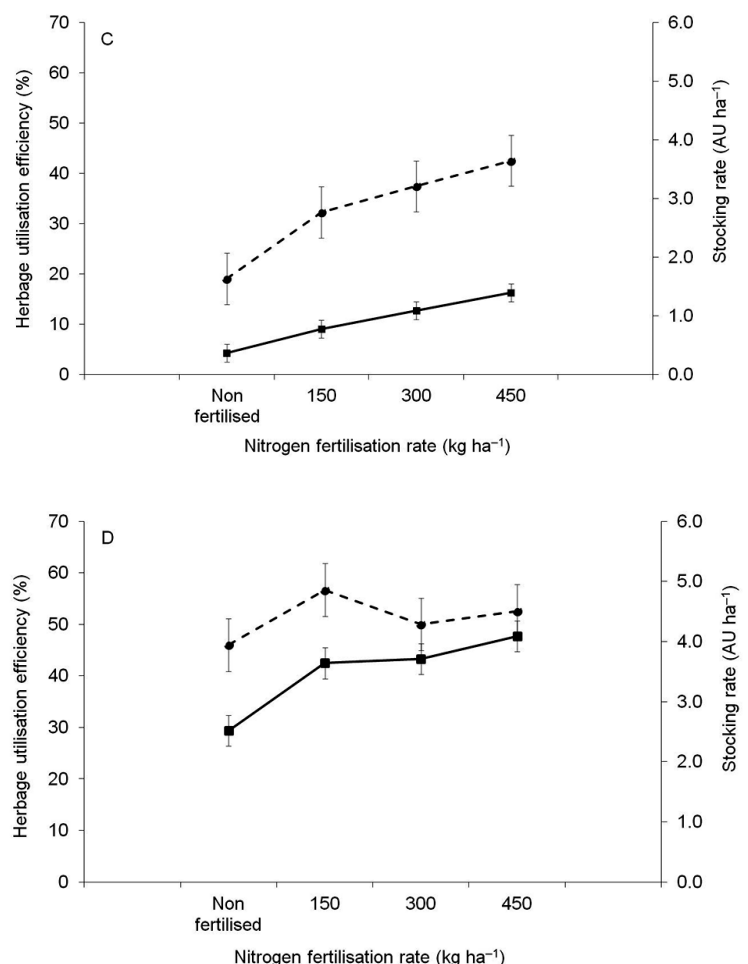

Nitrogen fertilisation rate $\left(\mathrm{kg} \mathrm{ha}^{-1}\right)$

Figure 3 - Stocking rate (solid lines) and herbage utilisation efficiency (dotted lines) of continuously stocked marandu palisade grass maintained at $30 \mathrm{~cm}$ and fertilised with nitrogen $(A=$ summer $\mathrm{I} ; \mathrm{B}=$ autumn/winter; $C=$ early spring; $D=$ late spring and $E=$ summer II). 


\section{Discussion}

In general, leaf appearance (LAR) and elongation rates (LER) were strongly influenced by nitrogen fertilisation in late spring, summer I and summer II (Table 2), periods of high availability of environmental growth factors. On average, during the recorded period values of LAR and LER for swards fertilised with 450 $\mathrm{kg} \mathrm{ha}{ }^{-1} \mathrm{~N}$ were 56 and $57 \%$ higher than those for non-fertilised swards, respectively, indicating a strong influence of nitrogen fertilisation on both LAR and LER. This response pattern is different from what is commonly described in the literature, mainly based on evidence from experiments with temperate forage grasses. Cruz and Boval (2000) reviewed the effect of nitrogen on a number of morphogenetic traits of temperate and tropical perennial forage grasses and commented that in tufted species the only aerial organs produced would be leaves and in stoloniferous species they would correspond to leaves and stems (stolons).

Because of such morphological differences, nitrogen fertilisation would have a strong influence on LER, FLL and tillering and only a slight effect on LAR in tufted species. On the other hand, in stoloniferous species, a significant influence would be on SER, LAR (due to internode elongation), LER and tillering as well as a minor influence on FLL /due to reduced leaf elongation duration). However, for certain other tropical forage grasses, recent evidence on nitrogen fertilisation has demonstrated a consistent increase in both LER and LAR under a wide range of experimental conditions for different perennial forage grass species (Brachiaria brizantha cv. Marandu - Alexandrino et al. (2006), Panicum maximum cv. Tanzânia - Patês et al. (2007), and Panicum maximum cv. Massai Martuscello et al. (2006) under glasshouse conditions; Panicum maximum cv. Mombaça - Pereira et al. (2011), and Andropogon gayanus - Magalhães et al. (2013) in small-plot experiments; and Panicum maximum cv. IRP-86 Milênio - Basso et al. (2010) in a paddock scale experiment). This is indicative of intermediate morphogenetic behaviour, and is most likely related to the significant stem elongation process that occurs during the vegetative growth stage of these plants ( $\mathrm{Da}$ Silva et al., 2009), that is, tufted plants that produce both leaves and stems as aerial organs.

Assuming a direct relationship between growth meristem elevation (internode elongation) and the length of the pseudostem (sheath tube length) (Skinner and Nelson, 1995; Lemaire and Chapman, 1996; Cruz and Boval, 2000; Duru and Ducrocq, 2000b) during vegetative growth of these tropical forage grasses, the higher values of LAR recorded in this experiment for swards fertilised with the higher rates of nitrogen seem to be unrelated to internode elongation. This is because the average stem length (SL) and the final leaf lamina length (FLL) remained relatively stable throughout the experiment for all nitrogen fertilisation treatments (Table 4), a condition indicative of swards being adapted to the imposed grazing management (Pereira et al., 2010).

LAR depends on the growth duration inside the sheath tube until the lamina becomes visible, which in turn is determined by the length of the sheath tube and the LER during that trajectory (Duru and Ducrocq, 2000a). Differences in LER would be explained by the positive effect of $\mathrm{N}$ supply on cell division and elongation at the leaf growth zone inside the sheath tube (MacAdam et al., 1989; Schnyder et al., 2000). Therefore, in situations in which the sheath tube length remains relatively stable, as in the present experiment, variations in LAR are basically a function of the LER inside the sheath tube. This functional relationship was adequately described by an exponential function between LER and phyllochron (PHY) that assumed equal LER inside and outside the sheath tube (Figure 4). The PHY can vary from 120 to around $1200{ }^{\circ} \mathrm{C}-\mathrm{d}$ (equivalent to 10 to around 100 days) for LER values higher than $1.0 \mathrm{~cm}$ per tiller $\mathrm{d}^{-1}$ or close to zero, respectively.

The described functional response is interpreted as possible genetic programming of the marandu palisade grass for matching periods of minimum and maximum leaf elongation duration (highest and lowest LAR, respectively) to the availability of environmental resources. This resource conservation strategy would be used by plants to maintain persistence when subjected to restricting conditions for growth and/or to avoid excessive losses of nutrients through senescence. The upper portion of the curve (high LER) comprises, in the main, data points generated during late spring, summer I and summer II, seasons of active plant growth. Under these conditions, higher values of LER for the same phyllochron were recorded for swards fertilised with 300 and $450 \mathrm{~kg} \mathrm{ha}^{-1} \mathrm{~N}$ relative to those for non-fertilised or fertilised with $150 \mathrm{~kg} \mathrm{ha}^{-1} \mathrm{~N}$. On the other hand, in the lower portion of the curve, comprising, in the main,

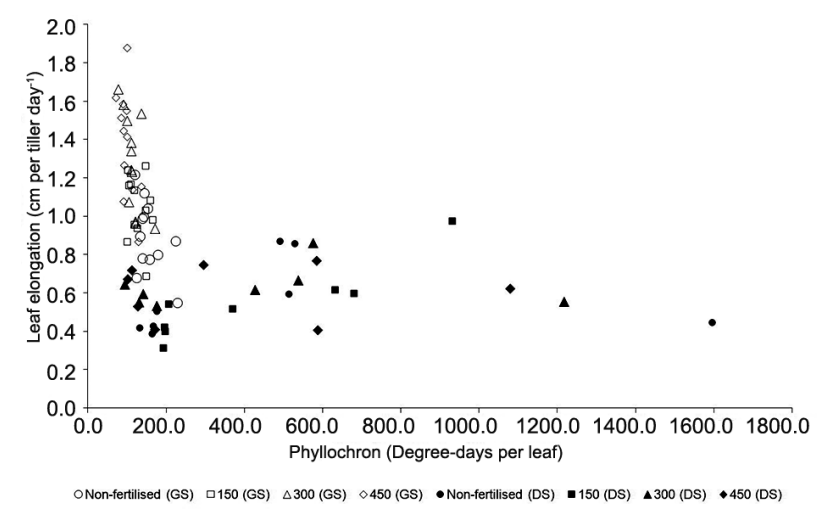

Figure 4 - Relationship between leaf elongation rate and phyllochron of continuously stocked marandu palisade grass maintained at 30 $\mathrm{cm}$ and fertilised with nitrogen from Jan 2007 to Apr 2008 (GS = growth season - summer I, late spring and summer II; DS = dry season - autumn/winter and early spring). 
data points generated during autumn, winter and early spring, seasons of low plant growth, nitrogen fertilisation treatments did not affect the relationship between LER and phyllochron (Figure 4). This could probably be a consequence of the soil water deficit and/or low temperatures, characteristic features of this time of year (Mesquita et al., 2010), and highly influential on LAR and LER (Lemaire and Chapman, 1996; Cruz and Boval, 2000), suggesting a plastic response in leaf elongation duration of the marandu palisade grass to both $\mathrm{N}$ status and climatic conditions.

Lemaire and Chapman (1996) conceptualised the direct dependence of the number of live leaves per tiller (NLL) on the ratio between leaf lifespan and phyllochron. The NLL is a structural characteristic genetically determined that remained relatively stable at around 3.5 to 3.8 leaves per tiller throughout the experimental period, regardless of nitrogen fertilisation treatment. Assuming that plants are genetically programmed for a maximum rate of growth under non-limiting conditions, in order to keep the number of live leaves per tiller stable, the leaf lifespan had to be compromised as a means of maintaining high rates of growth. The LLS was shorter in autumn/winter, late spring, summer I and summer II (329 to $711^{\circ} \mathrm{C}$ d) relative to early spring (2118 to $2394{ }^{\circ} \mathrm{C}$-d), a time of more pronounced soil water deficit, particularly in swards fertilised with 300 and $450 \mathrm{~kg} \mathrm{ha}^{-1} \mathrm{~N}$ (Table 4). This was in line with the highest rates of leaf senescence recorded in early spring (Table 2). This demonstrates a seasonal pattern of variation in LLS and LSR in tropical forage grasses due to changing environmental conditions, a consequence of the morphogenetic responses and the growth strategies of plants. Such a response pattern was described for $\mathrm{C}_{3}$ species (Lemaire et al., 2009) previously.

The short longevity of leaves is associated with high rates of growth and carbon fixation, while long longevity contributes to the conservation of nutrients in plant tissues (increased residence time of nutrients in plant tissues) (Navas et al., 2003); suggesting that at times of high availability of growth factors, plants would rely on resource capture strategies for survival and at times of limiting growth conditions strategies would change to resource conservation. In this context, short leaf lifespan in productive habitats would be the logical consequence of maximisation of plant growth (Ryser and Urbas, 2000) and optimisation of the competitive ability of plants (Briske, 1996).

Reduced growth rates had to be matched by lower stocking rates (Table 1), which resulted in reduced defoliation frequency of leaves (Figure 2) and lower herbage utilisation efficiency during autumn/winter $(30.8 \%)$ and early spring $(32.8 \%)$ relative to late spring (51.3\%), summer I (46.6\%) and summer II (56.0\%). Except for early spring, these results are in line with what would be expected from the general relationship between defoliation frequency and stocking density under continuous stocking management as proposed by Lemaire et al. (2009). According to these authors, higher growth rates require higher stocking rates to maintain a given target of sward management that, in turn, result in higher defoliation frequency of leaves and increased number of defoliations during leaf lifespan $(0.62 \pm 0.038,0.57 \pm 0.043,1.78 \pm 0.163,0.79 \pm$ 0.036 and $0.83 \pm 0.039$ for summer I, autumn/winter, early spring, late spring and summer II, respectively), thereby increasing herbage utilisation efficiency (Figure 3). In early spring, however, LLS was 4 to 5 times longer than during the remaining seasons of the year (Table 3), which more than compensated for the reduced frequency of defoliation, resulting in the largest number of defoliations during leaf lifespan (1.78 \pm 0.163$)$. In spite of this, herbage utilisation efficiency was as low as in autumn/winter because of the 2 to 3 fold higher rates of leaf senescence (Table 2). This fact highlights the complex nature of the balance between processes determining herbage growth and utilisation under grazing conditions, and also indicates that opportunity for augmenting utilisation efficiency is greater at times of active plant growth, namely late spring and summer in this experiment (Figure 3).

Except for early spring, nitrogen fertilisation caused a reduction in LLS (Table 3), a contrasting response from that reported by Mazzanti and Lemaire (1994), which was characterised by increased leaf defoliation frequency with no change in leaf lifespan. In this experiment, the increased defoliation frequency of leaves (Figure 2), consequence of the higher stocking rates necessary to match the higher growth rates and to maintain the management target, was compensated for by the reduction in LLS. As a result, the number of defoliations during leaf lifespan was similar for all nitrogen fertilisation treatments $(0.85,0.89,0.98$ and $0.94 \pm 0.069$ for non-fertilised swards and those fertilised with 150,300 and $450 \mathrm{~kg} \mathrm{ha}^{-1}$ of $\mathrm{N}$, respectivly). This, associated with a similar severity of defoliation (53.7, 56.4, 56.4 and $58.1 \pm 1.88 \%$ for non-fertilised and swards fertilised with 150, 300 and $450 \mathrm{~kg} \mathrm{ha}^{-1}$ $\mathrm{N}$, respectively), explains the absence of difference in herbage utilisation efficiency between swards fertilised with nitrogen.

The only difference detected was between nonfertilised and swards fertilised with $150 \mathrm{~kg} \mathrm{ha}^{-1}$ (Figure 3). In several situations leaf lifespan is negatively correlated with nitrogen concentration in plant tissue and with the supply of nutrients under adequate growth conditions (availability of light, water, favourable temperatures and other micro environmental factors) (Craine and Reich, 2001). Chemical analysis of samples of the last fully expanded leaf, considered an adequate field indicator of the nitrogen nutrition status of plants (critical level = 14.4 to $22.0 \mathrm{~g} \mathrm{~kg}^{-1}$; Batista and Monteiro, 2007), revealed higher $\mathrm{N}$ concentration for swards fertilised with the higher rates of nitrogen, and sub-optimal levels for those fertilised with $150 \mathrm{~kg} \mathrm{ha}^{-1}$ and non-fertilised. In this con- 
text, the additional supply of nitrogen provided by the $150 \mathrm{~kg} \mathrm{ha}^{-1}$ rate resulted in the largest increase in stocking rate relative to that between the remaining rates of nitrogen fertilisation (Table 1). This suggests that if the range of stocking rates used for the nitrogen fertilisation treatments had been wider, differences in herbage utilisation efficiency could have been detected in spite of the shorter LLS of fertilised swards. This is corroborated by the differences in herbage utilisation efficiency between seasons of the year discussed above.

On average, the stocking rate varied from 0.6 to 4.5 $\mathrm{AU} \mathrm{ha} \mathrm{ha}^{-1}$ for seasons of the year and from 1.6 to 3.1 AU ha ${ }^{-1}$ for nitrogen fertilisation treatments, an increase by a factor of 7.5 and 1.9 between the lowest and the highest values, respectively. Additionally, the present experiment was conducted using as a management target the sward surface height and that used by Mazzanti and Lemaire (1994), sward leaf area index (LAI). This proved to be a significant difference, since for the same management height of $30 \mathrm{~cm}$, nitrogen fertilisation resulted in an average increase in LAI of about $100 \%$ (contrast between 0 and $450 \mathrm{~kg} \mathrm{ha}^{-1} \mathrm{~N}$ ) throughout the experimental period (Table 1).

If the experiment was to be carried out using LAI as the management target, swards fertilised with nitrogen would have to be maintained at lower heights. In order to achieve this, higher stocking rates would have to be used, increasing the range between minimum and maximum values and most likely resulting in differences of herbage utilisation efficiency, as measured for Festuca arundinacea by Mazzanti and Lemaire (1994). In the present experiment, LAI and LLS did not vary between non-fertilised swards and those fertilised with $150 \mathrm{~kg}$ $\mathrm{ha}^{-1}$ during periods of active plant growth (summer I, late spring and summer II), the only cases where an increase in herbage utilisation efficiency was detected (Figure 3).

In spite of the absence of differences in herbage utilisation efficiency between swards fertilised with nitrogen, the supply of this nutrient at a rate of $150 \mathrm{~kg} \mathrm{ha}^{-1}$ did improve utilisation efficiency in relation to non-fertilised swards, highlighting its importance and the need to know the $\mathrm{N}$ nutrition status of plants to make inferences about the use and efficacy of nitrogen fertiliser application. Additional benefits of nitrogen fertilisation would also be associated with the enhanced nutritive value of the herbage produced (Santos et al., 2006), due to the higher tissue and tiller turnover on swards fertilised with the higher rates of nitrogen (Caminha et al., 2010), and higher growth potential of younger tillers under these conditions (Paiva et al., 2011; Paiva et al., 2012). The way to increase HUE under a rigid continuous stocking management would be to increase the probability of defoliation of leaves. This could be achieved through increases in stocking rate via a slight and strategic reduction in sward height at certain times of the year (e.g. variable management target). The limit to which this could be accomplished without compromising animal performance needs further study. Nevertheless, a relatively low HUE (as observed in this experiment) could have a number of important benefits for the ecosystem such as increased nutrient cycling and carbon mitigation (provided it is associated with acceptable levels of animal production).

\section{Acknowledgements}

Thanks are due to Dr André Fischer Sbrissia for valuable comments during the elaboration of this paper, to the São Paulo State Foundation for Research Support (FAPESP) and the Brazilian National Council for Scientific and Technological Development (CNPq) for financial support and to the research team at USP/ ESALQ, Brazil.

\section{References}

Alexandrino, E.; Nascimento Júnior, D.; Mosquim, P.R.; Regazzi, A.J.; Rocha, F.C. 2006. Morphogenesis and structural characteristics of regrowth of Brachiaria brizantha cv. Marandu assigned to three nitrogen levels. Revista Brasileira de Zootecnia 33: 1372-1379 (in Portuguese, with abstract in English).

Barthram, G.T. 1985. Experimental techniques: the HFRO sward stick. p. 29-30. In: Alcock, M.M., ed. Biennial report of the hill farming research organization. HFRO, Penicuik, UK.

Basso, K.C.; Cecato, U.; Lugão, S.M.B.; Gomes, J.A.N.; Barbero, L.M.; Mourão, G.B. 2010. Morphogenesis and dynamics of tillering in a pasture of Panicum maximum Jacq. cv. IPR86 Millennium under increasing doses of nitrogen. Revista Brasileira de Saúde e Produção Animal 11: 976-989 (in Portuguese, with abstract in English).

Batista, K.; Monteiro, F.A. 2007. Nitrogen and sulphur in marandu grass: relationship between supply and concentration in leaf tissues. Scientia Agricola 64: 44-51.

Briske, D.D. 1996. Strategies of plant survival in grazed systems: a functional interpretation. p. 37-67. In: Hodgson, J.; Illius, A.W., eds. The ecology and management of grazing systems. $\mathrm{CAB}$ International, Wallingford, UK.

Caminha, F.O.; Da Silva, S.C.; Paiva, A.J.; Pereira, L.E.T.; Mesquita, P.; Guarda, V.D. 2010. Stability of tiller population of continuously stocked marandu palisade grass fertilized with nitrogen. Pesquisa Agropecuária Brasileira 45: 213-220 (in Portuguese, with abstract in English).

Craine, J.M.; Reich, P.B. 2001. Elevated $\mathrm{CO}_{2}$ and nitrogen supply alter leaf longevity of grassland species. New Phytologist 150: 397-403.

Cruz, P.; Boval, M. 2000. Effect of nitrogen on some morphogenetic traits of temperate and tropical perennial forage grasses. p. 151-168. In: Lemaire, G.; Hodgson, J.; Moraes, A.; Nabinger, C.; Carvalho, P.C.F., eds. Grassland ecophysiology and grazing ecology. CAB International, Wallingford, UK.

Da Silva, S.C.; Nascimento Júnior, D. 2007. Research advances in tropical grasses on pasture: morphophysiological characteristics and grazing management. Revista Brasileira de Zootecnia 36: 121-138 (in Portuguese, with abstract in English). 
Da Silva, S.C.; Bueno, A.A.O.; Carnevalli, R.A.; Uebele, M.C.; Bueno, F.O.; Hodgson, J.; Matthew, C.; Arnold, J.C.; Morais, J.P.G. 2009. Sward structural characteristics and herbage accumulation of Panicum maximum cv. Mombaça subject to rotational stocking managements. Scientia Agricola 66: 8-19.

Duru, M.; Ducrocq, H. 2000a. Growth and senescence of the successive leaves on a Cocksfoot tiller: effect of nitrogen and cutting regime. Annals of Botany 85: 645-653.

Duru, M.; Ducrocq, H. 2000b. Growth and senescence of the successive grass leaves on a tiller: ontogenic development and effect of temperature. Annals of Botany 85: 635-643.

Lemaire, G.; Agnusdei, M. 2000 Leaf tissue turnover and efficiency of herbage utilization. p. 265-288. In: Lemaire, G.; Hodgson, J.; Moraes, A.; Carvalho, P.C.F.; Nabinger, C., eds. Grassland ecophysiology and grazing ecology. CAB International, Wallingford, UK.

Lemaire, G.; Chapman, D. 1996. Tissue fluxes in grazing plant communities. p. 3-36. In: Hodgson, J.; Illius, A.W., eds. The ecology and management of grazing systems. $\mathrm{CAB}$ International, Wallingford, UK.

Lemaire, G.; Da Silva, S.C.; Agnusdei, M.; Wade, M.; Hodgson, J. 2009. Interactions between leaf lifespan and defoliation frequency in temperate and tropical pastures: a review. Grass and Forage Science 6: 341-353.

MacAdam, J.W.; Volenec, J.J.; Nelson, C.J. 1989. Effects of nitrogen on mesophyll cell division and epidermal cell elongation in tall fescue leaf blades. Plant Physiology 89: 549-556.

Magalhães, J.A.; Carneiro, M.S.S.; Andrade, A.C.; Pereira, E.S.; Andrade, A.P.; Bakke, O.A.; Rodrigues, B.H.N.; Mochel Filho, W.J.E.; Costa, N.L. 2013. Morphogenetic and structural characteristics of andropogon grass under irrigation and fertilization. Semina: Ciências Agrárias 34: 2427-2436 (in Portuguese, with abstract in English).

Martuscello, J.A.; Fonseca, D.M.; Nascimento Júnior, D.; Santos, P.M.; Cunha. D.N.F.V.; Moreira, L.M. 2006. Morphogenetic and structural characteristics responses of massaigrass under nitrogen fertilization and defoliation. Revista Brasileira de Zootecnia 35: 665-671 (in Portuguese, with abstract in English).

Mazzanti, A.; Lemaire, G. 1994. Effect of nitrogen fertilization on herbage production of tall fescue continuously grazed by sheep. 2. Consumption and herbage efficiency utilization. Grass and Forage Science 49: 352-359.

Mendonça, F.C.; Rassini, J.B. 2006. Lower base temperature and seasonal production of tropical forage grasses. EMBRAPA Pecuária Sudeste, São Carlos, Brazil. (Circular Técnica, 45) (in Portuguese).

Mesquita, P.; Da Silva, S.C.; Paiva, A.J.; Caminha, F.O.; Pereira, L.E.T.; Guarda, V.D.A.; Nascimento Júnior, D. 2010. Structural characteristics of marandu palisadegrass swards subjected to continuous stocking and contrasting rhythms of growth. Scientia Agricola 67: 23-30.
Navas, M.L.; Ducout, B.; Rournet, C.; Richarte, J.; Garnier, J. 2003. Leaf life span, dynamics and construction cost of species from Mediterranean old-fields differing in successional status. New Phytologist 159: 213-228.

Paiva, A.J.; Da Silva, S.C.; Pereira, L.E.T.; Caminha, F.O.; Pereira, P.M.; Guarda, V.D.A. 2011. Morphogenesis on age categories of tillers in marandu palisadegrass. Scientia Agricola 68: 626-631.

Paiva, A.J.; Da Silva, S.C.; Pereira, L.E.T.; Guarda, V.D.A.; Pereira, P.M.; Caminha, F.O. 2012. Structural characteristics of tiller age categories of continuously stocked marandu palisade grass swards fertilized with nitrogen. Revista Brasileira de Zootecnia 41: 24-29 (in Portuguese, with abstract in English).

Patês, N.M.S.; Pires, A.J.V.; Silva, C.C.F.; Santos, L.C.; Carvalho, G.G.P.; Freire, M.A.L. 2007. Morphogenetic and structural characteristics of tanzaniagrass submitted to phosphorus and nitrogen fertilization. Revista Brasileira de Zootecnia 36: 17361741 (in Portuguese, with abstract in English).

Pereira, L.E.T.; Paiva, A.J.; Da Silva, S.C.; Caminha, F.O.; Guarda, V.D.A.; Pereira, P.M. 2010. Structural characteristics of tiller age categories of continuously stocked marandu palisade grass swards fertilized with nitrogen. Scientia Agricola 67: 531-539.

Pereira, V.V.; Fonseca, D.M.; Martuscello, J.A.; Braz, T.G.S.; Santos, M.V.; Cecon, P.R. 2011. Morphogenic and structural characteristics of Panicum maximum Jacq. cv. Mombaça under three densities of fertilization with nitrogen. Revista Brasileira de Zootecnia 40: 2681-2689 (in Portuguese, with abstract in English).

Ryser, P.; Urbas, P. 2000. Ecological significance of leaf life span among Central European grass species. Oikos 91: 41-50.

Santos, P.M.; Corsi, M.; Pedreira, C.G.S.; Lima, C.G. 2006. Tiller cohort development and digestibility in Tanzania guinea grass (Panicum maximum cv. Tanzânia) under three levels of grazing intensity. Tropical Grasslands 40: 84-93.

Schnyder, H.; Schäufele, R.; Visser, R.; Nelson, J.C. 2000. An integrated view of $\mathrm{C}$ and $\mathrm{N}$ uses in leaf growth zones of defoliated grasses. p. 41-60. In: Lemaire, G.; Hodgson, J.; Moraes, A.; Nabinger, C.; Carvalho, P.C.F., eds. Grassland ecophysiology and grazing ecology. CAB International, Wallingford, UK.

Skinner, R.H.; Nelson, C.J. 1995. Elongation of the grass leaf and its relationship to the phyllochron. Crop Science 35: 4-10.

Werner, J.C. Paulino, V.T.; Cantarella, H.; Andrade, N.O.; Quaggio, J.A. 1996. Forage. p. 263-273. In: Raij, B. van; Cantarella, H.; Quaggio, J.A.; Furlani, A.M.C., eds. Recommendations for fertilising and liming for the state of São Paulo. Boletim Técnico 100, Instituto Agronômico, Campinas, Brazil (in Portuguese).

Wolfinger, R.D. 1993. Covariance structure selection in general mixed models. Communications in Statistics Simulation and Computation 22: 1079-1106. 